\title{
Vrede in die boek van Esegiël
}

\begin{tabular}{|c|c|}
\hline \multicolumn{2}{|c|}{$\begin{array}{l}\text { Author: } \\
\text { Herculaas (Herrie) F. van } \\
\text { Rooy }^{1}\end{array}$} \\
\hline \multicolumn{2}{|c|}{$\begin{array}{l}\text { Affiliation: } \\
{ }^{1} \text { School of Ancient Languages } \\
\text { and Text Studies, North-West } \\
\text { University, Potchefstroom } \\
\text { Campus, South Africa }\end{array}$} \\
\hline \multicolumn{2}{|c|}{$\begin{array}{l}\text { Note: } \\
\text { This work is based on the } \\
\text { research supported by } \\
\text { the National Research } \\
\text { Foundation. Any opinion, } \\
\text { finding and conclusion or } \\
\text { recommendation expressed } \\
\text { in this material is that of } \\
\text { the author and the National } \\
\text { Research Foundation does } \\
\text { not accept any liability in this } \\
\text { regard. }\end{array}$} \\
\hline \multicolumn{2}{|c|}{$\begin{array}{l}\text { Correspondence to: } \\
\text { Herrie van Rooy }\end{array}$} \\
\hline \multicolumn{2}{|c|}{$\begin{array}{l}\text { Email: } \\
\text { herrie.vanrooy@nwu.ac.za }\end{array}$} \\
\hline \multicolumn{2}{|c|}{$\begin{array}{l}\text { Postal address: } \\
\text { Faculty of Theology, } \\
\text { North-West University, } \\
\text { Potchefstroom 2520, } \\
\text { South Africa }\end{array}$} \\
\hline \multicolumn{2}{|c|}{$\begin{array}{l}\text { Dates: } \\
\text { Received: } 21 \text { Mar. } 2015 \\
\text { Accepted: } 09 \text { May } 2015 \\
\text { Published: } 14 \text { Aug. } 2015\end{array}$} \\
\hline \multicolumn{2}{|c|}{$\begin{array}{l}\text { How to cite this article: } \\
\text { Van Rooy, H.F., 2015, 'Vrede } \\
\text { in die boek van Esegiël', } \\
\text { HTS Teologiese Studies/ } \\
\text { Theological Studies 71(1), } \\
\text { Art. \#2947, } 7 \text { pages. http:// } \\
\text { dx.doi.org/10.4102/hts. } \\
\text { v71i1.2947 }\end{array}$} \\
\hline \multicolumn{2}{|c|}{$\begin{array}{l}\text { Copyright: } \\
\text { (C) 2015. The Authors. } \\
\text { Licensee: AOSIS } \\
\text { OpenJournals. This work is } \\
\text { licensed under the Creative } \\
\text { Commons Attribution } \\
\text { License. }\end{array}$} \\
\hline \multicolumn{2}{|l|}{ Read online: } \\
\hline 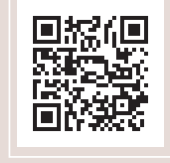 & $\begin{array}{l}\text { Scan this QR } \\
\text { code with your } \\
\text { smart phone or } \\
\text { mobile device } \\
\text { to read online. }\end{array}$ \\
\hline
\end{tabular}

Peace in the Book of Ezekiel. The prophet Ezekiel lived in a time when the people of Judah did not experience peace. He was a captive in Babylonia and preached to the exiles about the fall of Jerusalem, and after having heard about the fall, he preached about the restoration of the people. The book does not use the Hebrew word שָׁל very often; moreover, the Hebrew word does not always denote 'peace'. This article discusses the use of the word in Ezekiel, comparing it with the other prophetic books in the Old Testament. The word occurs only seven times in the book. In Ezekiel 7:25, it deals with a vain search for peace. In Ezekiel 13, the false prophets are admonished for proclaiming peace when there is no peace. In Ezekiel 34:25 and $37: 26$, a covenant of peace is proclaimed for the time of the eventual restoration of the people. The fact that 'peace' is not mentioned explicitly very often in the book can be related to the reaction of the prophet against the peace-prophets of his time.

\section{Inleiding}

Soos die ander twee groot profete het Esegiël, volgens die beskrywing van die boek self, geleef in 'n tyd waar daar maar min sprake van vrede was. Tog eindig die boek met 'n groot visioen van 'n volk wat herstel gaan word en na hulle land terugkeer. 'n Groot deel van die visioen handel oor die herstel van die tempel. Die hele prentjie aan die einde van die boek vertel die verhaal van 'n vredevolle tyd wat gaan aanbreek as God die herstel van sy volk bewerkstellig.

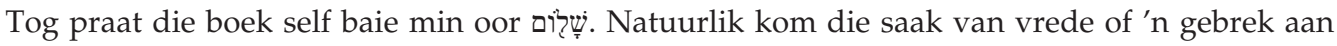
vrede dikwels voor waar die woord self nie voorkom nie. Die woord beteken ook nie altyd wat normaalweg onder 'vrede' verstaan word nie, sodat 'n mens versigtig daarmee moet omgaan. Hierdie artikel let op die gebruik van die woord שָׁלום in Esegiël, ook in vergelyking met die ander profetiese boeke van die Ou Testament. Die woord kom net sewe keer in Esegiël voor. Op grond van die konteks waar שָׁלום elke keer voorkom, word die betrokke teksgedeeltes in drie groepe verdeel, naamlik 'n teks wat dui op die volk wat vrede soek en dit nie kry nie, 'n gedeelte waarin valse profete 'n valse vrede verkondig, en twee teksgedeeltes wat van 'n 'verbond van vrede' praat. Hierbenewens word daar gelet op die voorkoms van vrede waar die woord vir vrede nie voorkom nie.

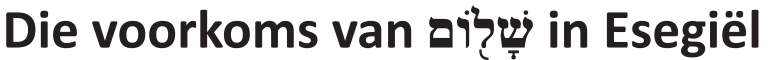

Verskillende geleerdes verdeel die boek op verskillende maniere, in onderafdelings. Die volgende drieledige indeling is baie gewild (vgl. Allen 1994:xxv; Sedlmeier 2002:49):

- 1-24: Profesieë (van oordeel) teen Israel voor die val van Jerusalem.

- 25-32: Profesieë teen die nasies.

- 33-48: Profesieë van hoop ná die val van Jerusalem.

Vir die doel van hierdie bydrae is veral die eerste en laaste gedeeltes belangrik. Die middelste gedeelte van die boek bevat profesieë teen die nasies, maar daar is nie eintlik sprake van vrede nie. Die eerste en derde gedeeltes van die boek kan soos volg in verdere onderafdelings ingedeel word:

- 1-24: Profesieë (van oordeel) teen Israel voor die val van Jerusalem.

- 1-3: Roepingsvisioen.

- 4-11: Tekens en gesigte wat oordeel oor Israel aankondig en veral teen Juda en Jerusalem gerig is.

- 12-24: Verdere oordeelsprofesieë.

- 33-48: Profesieë van hoop ná die val van Jerusalem.

- 33: Inleiding tot die laaste gedeelte van die boek.

- 34-39: Profesieë van hoop.

- 40-48: Die terugkeer van die Here na Jerusalem en die herstel van die volk, die land en die tempel. 
In Esegiël 1-3, ná die inleidende visioen, word die profeet gestuur na 'n volk (die ballinge) wat nie na hom wou luister nie. Esegiël 4-7 bevat oordeelsuitsprake teen Jerusalem. Die volgende gesig wat die profeet sien (Eseg 8-11), eindig met die vertrek van die heerlikheid van die Here uit die tempel en uit Jerusalem. In Esegiël 12-24 is die profesieë teen die valse profete in 13-14 baie belangrik. Esegiël 33 is die wentelpunt in die boek (vgl. Van Rooy 2012). Nadat die berig van die val van Jerusalem die profeet bereik het, kan hy weer begin praat. Esegiël 34-39 bevat verskeie gedeeltes waarin die herstel van die volk en hulle terugkeer na die beloofde land beklemtoon word. Die boek sluit af met die visioen van die terugkeer van die Here en die herstel van die tempel, die land en die volk. Die terugkeer van die heerlikheid van die Here word in Esegiël 43 beskryf. Die herstel van die land bereik 'n hoogtepunt in hoofstuk 47, waar die profeet sien dat 'n bietjie water onder die drumpel van die tempel uitvloei en 'n rivier word wat na die Dooie See stroom. Hierdie uiteensetting van die boek van Esegiël gee 'n raamwerk vir die voorkoms van die woord 'vrede' in die boek, asook vir die ander gedeeltes wat op vrede dui sonder dat die woord self daarin voorkom.

Die woord שָׁלום kom net sewe keer in die boek as geheel voor. Vyf hiervan word in die eerste deel en twee in die laaste deel gevind. In die eerste deel kom die woord een keer in Esegiël 4-11 en vier keer in Esegiël 13 voor. In die laaste deel van die boek kom dit in 33-39 voor en glad nie in die visioen van die herstel in Esegiël 40-48 nie. Laasgenoemde feit verdien besondere aandag. Die gedeelte beskryf die herstel in taal wat op 'n eskatologiese vrede dui, maar dit word gedoen sonder om die woord שָׁלוֹ te gebruik.

Die voorkoms van שָ Esegiël kan vergelyk word met die voorkoms van die woord in die Ou Testament as geheel. Natuurlik moet ' $n$ mens onthou dat die woord nie noodwendig in al die gevalle waar dit voorkom, 'vrede' beteken nie. Hier word net twee sulke voorbeelde uit die profete vermeld. In Jesaja 41:3 word daar na die kneg van die Here verwys:

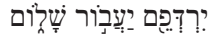

Die New International Version (NIV) vertaal dit soos volg: 'He pursues them and moves on unscathed.' Oswalt (1997:83) beskou die Hebreeuse שָָׁלוֹ hier as 'n 'adverbiale akkusatief'; dus 'n adjunk wat wyse aandui.

In Jeremia 15:5 word die woord in die gebruiklike groetformule gebruik (Stendebach 2006:37):

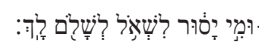

NIV: 'Who will stop to ask how you are?'

Volgens Gerleman (1997:1338-1339) kom die woord 237 keer in die Ou Testament voor en 80 hiervan word in die profetiese boeke gevind. Die verspreiding sien soos volg daar uit:

- Jesaja 29

- Jeremia 31
- Esegiël 7

- Obadja 1

- Miga 2

- Nahum 1

- Haggai 1

- Sagaria 6

- Maleagi 2

Wat dadelik opval, is die relatief min kere dat die woord in Esegiël voorkom in vergelyking met die ander twee groot profete. Dit is veral merkwaardig dat die woord net twee keer in die laaste gedeelte van die boek voorkom. In die bespreking sal dus ook aandag gegee moet word aan die vraag waarom dit lyk asof die profeet die woord doelbewus so min gebruik.

Die woord שָׁלום was al die onderwerp van heelwat studies, en die artikels van Stendebach (2006) en Gerleman (1997) bied 'n goeie oorsig daarvan. Volgens Gerleman (1997:1339) het die woord veral twee betekenisvelde, naamlik 'vrede' en 'vriendelikheid' enersyds en 'voorspoed' en 'sukses' andersyds. Roberts (2004:347) meen dat Israel vrede in hul vroeë nadenke nie beskou het as iets wat mense bereik het nie, maar as iets wat deur God gegee is.

\section{'n Vergeefse soeke na שָׁלוֹם in Esegiël 7:25}

Esegiël 7 sluit die groep profesieë af wat van Esegiël 4 tot 7 strek. Aan die begin van die boek word 'n datum vir die profeet se visioen gegee. Die volgende datum in die boek kom voor aan die begin van hoofstuk 8 , waarop ' $n$ volgende visioen van die profeet volg. Die hoofstuk vorm 'n afgeronde eenheid in die boek (vgl. Block 1997:240-241) en kan in drie afsonderlike eenhede verdeel word, naamlik vers 2-4, 5-9 en 10-27. Elke eenheid word afgesluit met die sogenaamde erkenningsformule (Block 1997:240): 'Dan sal jy besef dat Ek die Here is.' In hierdie formule is dit die land Israel wat deur die Here aangespreek word. Elkeen van die drie gedeeltes begin ook met 'n uitroep waarin die komende oordeel aangekondig word:
Vers 2: 'Mens, die einde kom! Die einde kom dwarsoor die land.'
Vers 5 en 6: 'Daar kom 'n ramp! 'n Groot ramp!
Die einde kom, die einde kom!
Dit begin jou tref, dit kom!'
Vers 10: 'Die dag is hier, dit kom, die ergste gaan gebeur.'

Dit is duidelik dat die oordeel voltrek gaan word. Daar kom oorlog en alles gaan vernietig word. Heel aan die einde van die hoofstuk, in vers 25-27, word beskryf hoe die volk gaan reageer wanneer die oordeel hulle gaan tref. Daar kom 'n groot ramp. Die mense sal geen raad of openbaring van die leiers van die volk kry nie - nie van die profete, priesters, oudstes, koning en al die vername mense nie. Agter die stilte van die leiers is die stilte van God, wat geen openbaring stuur nie (Allen 1994:111). Die godsdienstige en burgerlike leiers bied geen uitkoms nie (Block 1997:268). Die volk sal begin reageer deur na vrede te soek, maar dit sal 'n vergeefse soeke wees: 


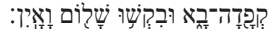

NIV: 'Terror is coming! They will seek peace, but it will be in vain.'

In die priesterlike seën in Numeri 6:25-26 volg vrede as die Here in genade na sy volk kyk (Allen 1994:111): 'Die Here sal julle gebede verhoor en aan julle vrede gee' (NAV). Wanneer sy oordeel voltrek word, verdwyn die vrede en word 'n gebed om vrede tevergeefs.

Hierdie verwysing na 'n vergeefse soeke na vrede is in 'n sekere sin uniek by Esegiël. Die gedagte is egter nie vreemd nie. In Jesaja 48 sê God dat, as die volk na sy gebooie geluister het, hulle inderdaad vrede sou beleef het: 'As jy maar aan my gebooie gehoorsaam was, sou daar voorspoed en redding vir jou gekom het, so onkeerbaar soos 'n rivier, soos die golwe van die see' (NAV). Hier vertaal die Afrikaanse Nuwe vertaling die Hebreeuse 22 kom 'vrede' wel voor wanneer die Here sê dat daar geen 'vrede' vir die goddeloses is nie (vgl. ook Jes. 57:21). In Jeremia 14:13 en 19 sê die volk dat hulle vir vrede gehoop het, maar dat dit nie gekom het nie. Hierdie uitspraak dat daar nie vrede is nie, kom nie vroeër as in Esegiël en Jeremia voor nie. Die wyse waarop Esegiël dit stel, is uniek. Die ander profete praat van vrede wat nie daar is nie, of van vrede waarop daar gehoop word. Die vergeefse soeke na vrede is egter net by Esegiël te vinde. In Esegiël 7 praat hy met die ballinge, maar hy beskryf die gesindheid van die mense in Juda en Jerusalem. Die wat agtergebly het, het reeds die wegvoering van koning Jojagin beleef en die komende vernietiging van Jerusalem het die soeke na vrede aangewakker, maar dit is 'n vergeefse soeke omdat hulle nie na God wil luister nie.

\section{'n Valse verkondiging van فָשרלום in Esegiël 13}

Die woord שָׁלום אבד kom vier keer in Esegiël 13 voor, binne die konteks van 'n oordeelsuitspraak oor en verwerping van valse profete wat vrede verkondig het terwyl daar nie vrede is nie. Die teks verwys na uitsprake wat die profete gemaak het voor die val van Jerusalem (Allen 1994:202). Die valse profete word verwyt dat hulle die volk op 'n dwaalspoor gelei het met 'n boodskap van vrede op 'n tydstip toe hulle eerder God se oordeel moes verkondig het en die volk moes opgeroep het om hulle van hulle verkeerde pad te bekeer. Hierdie verwysing na die verkondiging van valse vrede kom voor in vers $1-16$. Ná die inleiding in vers $1-3$ a word die valse profete in vers 3b-7 aangekla. Daarop volg twee oordeelsuitsprake, in vers 8-9 en 10-16 (vgl. Block 1997:393-394). Die tweede oordeelsuitspraak begin met die verwysing na die verkondiging van valse vrede. Die valse profete het gesê dat daar vrede sou wees, maar daar is geen vrede nie. Die uitspraak sluit ook af met 'n verwysing na hierdie valse verkondiging van vrede in vers 10 . Die valse profete het hulle ook op gesigte beroem. Hulle sou 'n gesig van vrede gesien het, maar daar is nie vrede nie.
Dat die verkondiging van God se oordeel en die oproep tot bekering die gepaste boodskap in die tyd voor die val van Jerusalem was, is baie duidelik in Esegiël 18. In dié hoofstuk beklemtoon die profeet dat elke persoon - en ook elke volk vir hulle eie optrede verantwoordelik is. Diegene wat verkeerd optree, sal onder die oordeel kom. Iemand wat hom egter bekeer, sal vergewe word en weer genade ontvang. As die volk God verwyt dat Hy nie reg optree nie, maak God dit duidelik dat hulle optrede verkeerd is. Die kern van wat die volk moet doen en wat die profete aan hulle moes verkondig het, word saamgevat in Esegiël 18:32, waar God sê: 'Dit is nie my wil dat die mens moet sterf nie ... maar dat hy hom bekeer en bly lewe.'

Hierteenoor maak 13:10 dit baie duidelik dat die valse profete nie hierdie boodskap van oordeel, wat aan 'n oproep tot bekering gekoppel is, aan die ballinge verkondig het nie, maar hulle eerder tot ' $n$ valse gerustheid verlei het:

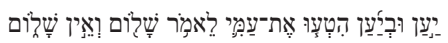

NIV: 'Because they lead my people astray, saying, "Peace", when there is no peace ...'

In hierdie konteks verwys vrede na vryheid van die militêre bedreiging van vyande, dit wil sê militêre en politieke stabiliteit (Stendebach 2006:38). Die vraag is wie hierdie valse profete was. Om hulle te verbind aan profete wat Josia se hervorming ondersteun het (Sweeney 2013:75-76), is moeilik om te aanvaar. Moontlik het die valse profete hulle op Jesaja beroep (Sweeney 2013:76). Tog dink 'n mens eerder aan profete soos Hananja wat in die laaste dae van Juda en Jerusalem opgetree het (Jeremia 23). Die aanklag teen die valse profete met hulle verkondiging van ' $n$ valse vrede is nie nuut nie. Sedlmeier (2002:177-179) gee 'n mooi oorsig van die saak van die valse profete in die Ou Testament. Reeds in Miga word 'n soortgelyke aanklag aangetref. In Miga 3:5 en 6 word die volgende gesê:

5 So sê die Here oor die profete wat my volk
die profete wat van vrede praat so lank hu
en as iemand hulle nie bly instop nie, oorlog
6 'Daar is vir julle net nag, nie 'n gesig nie,
donkerte, nie 'n voorspelling nie.
Die son sal ondergaan vir hierdie profete,
die dag sal pikdonker word oor hulle.'

Miga gebruik die boodskapperformule wat aan die begin van hierdie aanhaling staan net twee keer in die boek (vgl. 2:3). Smith (1984:33) noem hierdie soort profete "'peace" prophets'. Hulle profesieë word gekenmerk deur oor-optimisme. Hulle het geglo dat die Here in beheer van die hele wêreld is. Hy het 'n ewige verbond met Dawid gesluit en het belowe dat Jerusalem altyd die stad van God sal wees. Smith (1984:33) wys daarop dat hierdie profete nie die bepalings, die voorwaardes van die verbond begryp het nie. Miga weet dat die volk se volharding in sonde oordeel sal bring, maar die valse profete dink net aan vrede.

Die profeet wat by uitstek 'n geskil met die valse profete gevoer het, is Jeremia. 'n Formule wat baie soos Esegiël 13 
se uitsprake teen die valse profete klink, kom in Jeremia 6:14 voor. Dit is effe meer uitgebreid as Esegiël se formule:

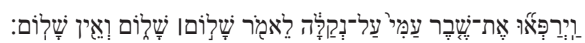

NIV: 'They dress the wound of my people as though it were not serious. "Peace, peace", they say, when there is no peace.'

Dieselfde formule kom ook in Jeremia 8:11 voor. In Jeremia 6 word ook oordeel oor die volk uitgespreek en die woorde herinner baie aan Esegiël 7. Die leiers van die volk is valse boodskappers wat die wonde - die sonde van die volk bedek met woorde wat 'n valse gerustheid bevorder. Dit is volgens McKane (1986:147) שָָָׁ-profesie sonder enige substansie.

'n Baie problematiese teks in die verband is Jeremia 4:10, waar die profeet eintlik die Here daarvan beskuldig dat Hy die boodskap van vrede aan die volk (laat) verkondig het: 'Toe sê ek: "Ag, Here my God! U het hierdie volk en Jerusalem bedrieg. U het gesê: "Julle sal vrede hê," maar nou lê die swaard teen ons kele"' (NAV). Oor die herkoms en betekenis van die vers bestaan daar baie meningsverskil. Die probleem van die verkondiging van vrede deur die valse profete was dat hulle vasgegryp het aan die onvoorwaardelike verbond wat God met Dawid gesluit het, sonder om hulle eie verantwoordelikheid te besef. Hierdie sogenaamde Sionsteologie is versterk deur die uitkoms wat die Ou Testament beskryf toe die Assiriërs Jerusalem in die tyd van Hiskia aangeval het en God op 'n wonderbaarlike wyse uitkoms gegee het. Craigie (1991:74) maak hieroor 'n belangrike stelling: 'The divine word for one situation is not necessarily the same for another situation, for the passage of time overtakes events, and in the process the people are deceived.' Hy sê verder dat dit eintlik 'n poging van die profeet was om vir die volk in te tree omdat hy die strengheid van die oordeel gesien het.

In Jeremia 14:13 kla die profeet oor die boodskap van valse gerustheid wat die profete verkondig het. Net voor die vers staan daar dat God hom verbied het om vir die volk te bid. Dit was die gevolg van die volk se volharding in sonde. In Jeremia 23:16 en 17 waarsku God die volk om nie na die profete te luister wat hierdie valse gerustheid verkondig het nie:

\footnotetext{
16 'Julle moenie luister na wat die profete sê nie,

die profete wat vir julle as profete optree.

Hulle wek vals verwagtings by julle,

hulle praat oor visioene wat hulle self uitdink,

nie oor wat die Here sê nie.

17 Hulle hou aan om vir dié wat My minag,

te sê: "Die Here sê daar sal vrede vir julle wees."

Vir dié wat hardkoppig is, sê hulle:

"Daar sal nie 'n ramp oor julle kom nie."'
}

Die bekendste voorbeeld van 'n gesprek tussen 'n ware en valse profeet is Jeremia se geskil met Hananja in Jeremia 23. Wat besonders in die uiteensetting is, is dat die vervulling van 'n voorspelling van vrede aangelê word as die toetssteen vir ware of valse profesie. Vers 9 (NIV) lui soos volg: 'But the prophet who prophesizes peace will be recognized as one truly sent by the Lord only if his prediction comes true.'

Dit is duidelik dat die saak van die verkondiging van valse vrede ' $n$ groter plek in Jeremia inneem as in Esegiël, waar dit beperk is tot Esegiël 13. Tog blyk hieruit dat die valse vrede en valse hoop in sowel Jerusalem as Babel verkondig is in die tyd ná die wegvoering van Jojagin en voor die vernietiging van Jerusalem. Terwyl die valse profete ' $n$ valse vrede verkondig het, het profete soos Jeremia en Esegiël nie gehuiwer om te sê dat daar weens die optrede van die volk geen vrede is nie (vgl. Penna 2010:284). Die valse profete het verhinder dat die volk hulle ware toestand erken (Sedlmeier 2002:184). Die profete moes die waarheid verkondig het, maar hulle het nie (Brueggemann 1988:1096). Alleen deur die komende oordeel sou God, wat die volk wou red en bewaar, die volk ontmoet (Zimmerli 1979:299).

\section{'n Verbond van vrede (Eseg 34:25 en 37:26)}

In Esegiël 34:25 en 37:26 word daar verwys na 'n verbond

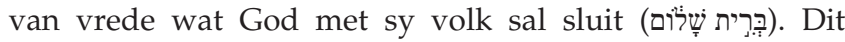
is die enigste twee keer dat die uitdrukking in hierdie vorm in die $\mathrm{Ou}$ Testament voorkom. Verbandhoudende uitdrukkings kom in Numeri 25:12 en Jesaja 54:10 voor. Hierdie vier gevalle, asook soortgelyke uitdrukkings in die Wysheid van Jesus Sirach en manuskripte uit Qumran, word volledig bespreek deur Egger-Wenzel (2010), wat 'n sterk eskatologiese betekenis hierin sien. Ook Batto (1987:187) sê dat die uitdrukking in eskatologiese visioene voorkom. Hy vind die agtergrond vir die uitdrukking in die Ou Testament in 'n ouer Nabye-Oosterse mite, waarin vertel word dat die gode van hulle kant die vyandskap beëindig het nadat die mens by die skepping teen die gode in opstand gekom het (Batto 1987:187). Die profete het hierdie motief egter na die eskatologiese periode verskuif (Batto 1987:188). Die teks in Numeri 25 hou volgens hom nie hiermee verband nie. Gerleman (1997:1344) wil die konsep van die verbond hier eerder verbind aan dade of gebeure in die verlede wat nie beloon is nie, eerder as aan beloftes wat vir die toekoms geld.

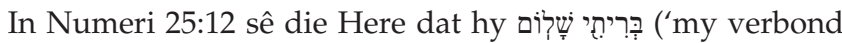
van vrede') met Pinehas sluit. Hy doen dit op grond van Pinehas se optrede by Sittim, waar die volk onsedelikheid bedryf het en Pinehas Simri en die Midianitiese vrou Kosbi om die lewe gebring het. Op grond hiervan ontvang Pinehas en sy nageslag die belofte van 'n blywende priesterskap (vgl. Egger-Wenzel 2010:36-38).

In Jesaja 54:10 sê die Here dat בְרִית שָׁלוֹמ̣י ('die verbond van my vrede' = 'my vredeverbond') nie sal wankel nie (vgl. EggerWenzel 2010:47-49). In hierdie geval het die uitdrukking duidelik eskatologiese betekenis en word dit verbind aan beloftes wat die Here oor die herstel van Jerusalem gegee het. In vers 9 word hierdie verbond van vrede eksplisiet met die verbond met Noag verbind. God se toorn het tot bedaring gekom en God het 'n eed geneem om nie weer die wêreld met 'n vloed te vernietig nie. Vir Batto (1987:190-191) dui 
hierdie verbinding van die verbond van vrede by Jesaja met die verbond met Noag op die herkoms van hierdie motief uit die voortyd.

Die uitdrukking kom ook voor in Esegiël 34, 'n hoofstuk waarin die herders van Israel verwyt word omdat hulle nie die Here se kudde versorg het nie (vgl. Egger-Wenzel 2010:52-54 vir 'n bespreking van die gedagtegang van die hoofstuk). Daarom sê die Here dat Hy self as die volk se herder gaan optree. Hy gaan ook vir Dawid as herder oor sy volk aanstel. Dit is een van die min kere waar so 'n belofte spesifiek aan Dawid verbind word. Die Here sê dan dat hy 'n verbond van vrede met die volk sal sluit. Oor die byvoeging van 'vrede' sê Zimmerli (1983:220): 'Covenant means the establishment of a relationship of well-being between the partners of the covenant.' Hierdie verbond sal onder andere inhou dat die roofdiere uitgeroei sal word en dat die volk rustig in hulle land sal kan woon. Hulle sal nie meer aan vyande oorgegee word nie (34:25 - NAV): 'Ek sal met hulle'n verbond sluit wat vir hulle vrede sal bring. Ek sal die roofdiere uitroei uit die land sodat my kleinvee veilig kan wees in die weiveld en in die bosse kan slaap.' Die verbondstaal blyk duidelik daaruit dat God sê dat Hy weer vir die volk 'n God sal wees en dat hulle sy volk sal wees (34:30 - NAV): 'Hulle sal besef dat Ek, die Here hulle God, by hulle is en dat hulle my volk Israel is, sê die Here my God.' Die verbondsformule, wat in vers 30 aangetref word, wys daarop dat die volk se posisie voor die Here herstel is, dat Hy weer hulle God is en dat hulle weer daarvan teenoor die volkere van die wêreld sal kan getuig (Sedlmeier 2013:178). Die Here bevestig ook die belofte van die verbond met 'n eed (Block 1999:303). Hierdie belofte gaan terug na die belofte wat God reeds aan die einde van Esegiël 16 gegee het. In 16:60 sê God dat Hy weer die verbond sal laat geld wat Hy met die volk in sy jeug gesluit het. Dit gaan dus hier oor 'n omkeer van die profesieë van oordeel wat vroeër in die boek aangetref word (Batto 1987:188-189).

Die belofte in Esegiël 34:25 herinner ook aan Levitikus 26:6 (NAV): 'Ek sal vrede gee in die land sodat julle rustig kan slaap: Ek sal die ongediertes uitroei en daar sal nie oorlog in julle land kom nie.' Levitikus 26:4-13 bevat 'n hele reeks verbondseëninge, waarby die beloftes van Esegiël 34 ten nouste aansluit, soos wat Block (1999:304) duidelik aantoon. Roofdiere gaan uitgeroei word, die land sal weer vrugbaar wees en vreemde oorheersers sal verwyder word. Daar is ook parallelle met Hosea 2:20-25 (17-22 in Afrikaans), waar soortgelyke uitsprake gemaak word. In die oordeel wat Esegiël oor die volk aangekondig het, het roofdiere ook 'n plek gehad (5:17, 14:15). In Esegiël 14:21 word die volgende as instrumente van oordeel genoem: oorlog, hongersnood, ongediertes en pes. Wanneer God weer die verbond herstel, kom beloftes van seëninge in die plek van oordeel. In die verbond van vrede word dus eintlik die driehoek van God, volk en land herstel (Block 1999:308) sodat die volk weer veilig in hulle land kan woon. Ware vrede word gevind in die herstelde verhouding met God. God sal in die nuwe verbond self as herder van die volk optree (Sweeney 2013:173). Die verwysing na die tuin van Eden bevestig vir Batto (1987:189) die gedagte dat Esegiël by 'n ou motief uit die voortyd aansluit.
Die uitdrukking "n verbond van vrede' kom ook in Esegiël 37:26 voor, in 'n gedeelte wat eintlik as 'n opsomming van die beloftes van Esegiël 34 beskou kan word (vgl. Egger-Wenzel 2010:54-58, vir 'n uiteensetting van die gedagtegang van die hoofstuk). Die vers lui soos volg (NAV):

Ek sal met hulle 'n verbond sluit wat vir hulle vrede sal bring, ' $n$ verbond wat altyd sal bestaan. Ek sal hulle baie laat word en my heiligdom tussen hulle oprig om altyd daar te wees.

Alhoewel daar kleiner verskille tussen die Hebreeuse en Griekse tekste van hierdie vers is, is dit nie werklik vir hierdie bespreking belangrik nie (vgl. Crane 2008:132-134). Hierdie verbond sal ook vir altyd duur. Die herkoms van hierdie 'ewige verbond' kan in Levitikus 24:8 nagespoor word (Block 1999:419). Die verbinding van die verbond van vrede met 'n ewige verbond wys op die onverganklikheid en onverbreekbaarheid van hierdie verbond (Sedlmeier 2013:234). Die beloftes wat hier gegee word, vertoon baie ooreenkomste met die beloftes in Levitikus 26:1-13 (Block 1999:420). Volgens Allen (1990:194) kom die verbond van vrede neer op ' $n$ verbinding van die verbond met Dawid met die verbond met die voorvaders. Sweeney (2013:185) verbind die verbond hier aan sowel Dawid as die nageslag van die priester Sadok. Israel en Juda sal weer 'n eenheid vorm onder 'n regeerder uit die huis van Dawid. Die herstel van die heiligdom is ook besonder belangrik in hierdie verband, iets waarop die groot visioen van Esegiël 40-48 weer terugkom (Zimmerli 1983:276). Die Here sal weer in hulle midde wees. Hulle sal weer sy volk wees en Hy hulle God. Die nasies sal dit ook erken. Dit is alleen God wat hierdie verbond van vrede, en dus ook vrede, kan bewerkstellig (Hanson 1984:347-348). Die mense moes dit hulle eie maak deur God se regverdigheid en medelye met alle mense uit te leef (Hanson 1984:356).

In albei die gedeeltes word klem daarop gelê dat God sy volk na hulle land sal terugbring en dat hulle daar veilig sal woon, soos wat ook in ander profetiese boeke gebeur (vgl. Roberts 2004, vir 'n bespreking van hierdie tema in verskeie profetiese boeke; hy verwys op bl. 13-14 in die besonder na die uitsprake van Esegiël in die verband). Die uitdrukking לָרָטָט kom telkens in Esegiël 34 voor, en ook in Esegiël 39. God sal vrede op die land laat woon nadat sy oordeel voltrek is (Batto 1987:211). Wanneer die volk na hulle land terugkeer, sal hulle veilig daar woon. Dit is die uitwerking van die herstelde vrede. God se heiligdom sal weer in hulle midde wees as teken van sy teenwoordigheid by hulle terug in hulle land. In hierdie uitspraak word die plek van die heiligdom in die besonder beklemtoon, iets waarop die laaste groot gedeelte van die boek, die visioen van 40-48, terugkom.

\section{Vrede op 'n ander manier uitgedruk as met die woord}

In die eerste gedeelte van die boek, waarin daar veral oordeel oor Juda en Jerusalem uitgespreek word, word daar na baie sake verwys. Tog is daar twee sake wat 'n mens telkens in die oordeeluitsprake opval. Dit is die ballingskap (die verstrooiing van die volk is die uitdrukking wat dikwels 
gebruik word) en die feit dat God sy volk verlaat het. In die afdeling hierbo is aangedui dat die terugkeer na die land en die terugkeer van God na sy volk 'n belangrike rol gespeel het in die verkondiging van die verbond van vrede wat God met die volk gaan sluit.

Dat God sy volk verlaat het, blyk baie duidelik uit die tweede visioen wat Esegiël gesien het, in Esegiël 8-11. In die gesig, waarin Esegiël na die tempel in Jerusalem geneem is, het hy gesien hoe die heerlikheid van die Here uit die tempel en die stad verdwyn het. In Esegiël 9:3 styg die heerlikheid op van die gerub waarop dit was, na die drumpel van die tempel. In 10:4 styg dit op van die drumpel en vul die voorhof van die tempel. In 10:18 vertrek dit verder van die drumpel. In 11:23 vertrek dit uit die stad uit. 'n Belangrike deel van die visioen van Esegiël 40-48 is die terugkeer van die heerlikheid van die Here na die tempel, in Esegiël 43. In vers 3-4 word beskryf hoe die heerlikheid van die Here van die ooste af gekom het in die tempel in. In vers 5 staan dat die heerlikheid van die Here die huis gevul het, soos wat gebeur het by die ingebruikneming van die tempel in die tyd van Salomo. As God nie terugkeer nie, kan daar geen vrede wees nie.

Wat die verlies van die land en die terugkeer daarna betref, vermeld Esegiël dikwels dat die Here die volk onder die lande en volke verstrooi het. Hierdie verstrooiing word verbind aan die volk se ongehoorsaamheid in Esegiël 20:23-24 (NAV):

Ek het ook daar in die woestyn 'n eed afgelê dat Ek hulle onder die nasies sou verstrooi, hulle oor ander lande sou versprei. Hulle het immers nie my bepalings nagekom nie, hulle het my voorskrifte verwerp, my Sabbatte ontheilig en by hulle voorvaders se afgode hulp gesoek.

Net so dikwels word dit egter duidelik gestel dat die Here sy volk sal laat terugkeer uit die ballingskap. Die ballingskap en die terugkeer sou die volk en die nasies God se mag laat besef. Dit word direk voor die beskrywing van die slotvisioen soos volg in Esegiël 39:28 (NAV) gestel:

Hulle sal besef dat Ek die Here hulle God is. Nadat Ek hulle in ballingskap laat wegvoer het na ander nasies toe, sal Ek hulle weer in hulle land bymekaarbring; niemand sal in ballingskap agterbly nie.

Die twee belangrike temas van die terugkeer van die Here se heerlikheid en die terugkeer uit die ballingskap was dus deel van die herstel van die volk. Dit sou 'n periode van vrede bring, soos wat in die slotvisioen beskryf word. Hierdie slotvisioen kry egter ook 'n meer universele betekenis, soos wat deur Eichrodt (1968:415) en Ackroyd (1968:168) opgemerk word. Darr verskil van hierdie mening en oordeel dat die vredevolle toekoms waarna Esegiël verwys, net vir die herstelde Israel geld (1987:278-279).

In aansluiting by die opmerkings hierbo kan daar gevra word waarom die woord vir vrede so min in die boek voorkom as daar tog duidelik 'n boodskap van vrede is, veral aan die einde van Esegiël 34 en verder. Die wyse waarop die woord gebruik word, werp in 'n mate lig hierop. Aan die begin van die boek staan die profeet baie sterk afwysend teen die verkeerde verkondiging van vrede en die valse soeke na vrede. Hierin sluit hy aan by 'n profeet soos Jeremia, wat ook afwysend teen die valse soeke na vrede gestaan het. Jeremia het in sy boodskap aangesluit by 'n Deuteronomistiese verbondsbeskouing, soos in Deuteronomium self uitgespel word. In die boek word die saak van oordeel oor ongehoorsaamheid baie sterk beklemtoon en die volk word opgeroep om die gebooie te gehoorsaam. In Esegiël kom daar baie min van daardie verbondsbeskouing na vore. Waar hy positief oor die verbond praat, soos in 34 en 37 , sluit hy eerder aan by die Abrahamitiese en veral die Dawidiese verbond. Dit is juis die laasgenoemde verbond wat die grond vir die valse verkondiging van vrede by die valse profete was. Omdat Esegiël self uit die priesterlike kring gekom het, waar die Sionsteologie met sy verkondiging van onvoorwaardelike vrede die basiese teologiese vertrekpunt was, het hy afwysend teen daardie soort verkondiging van vrede gestaan. Sy priesterlike agtergrond blyk onder andere uit sy gebruik van beloftes en strawwe soos in Levitikus 26, en nie soos in Deuteronomium 28, soos wat by Jeremia aangetref word nie. Dit is waarom hy in sy positiewe verkondiging van vrede spesifiek van 'n verbond van vrede praat, waardeur hy die Dawidiese verbond in die konteks van God se nuwe genade na die ballingskap wou stel.

\section{Slot}

Die woord vir vrede kom net sewe keer in Esegiël voor, baie minder as in die ander groot profete. Die woord word in drie kontekste gebruik, naamlik die vergeefse soeke na vrede, die afwysing van die verkondiging van valse vrede deur valse profete en ' $n$ verbond van vrede in die konteks van die belofte van 'n herstelde verhouding met God. In die oordeelsuitsprake in die boek kom veral twee sake na vore, naamlik die verstrooiing van die volk in ballingskap en dat God sy volk verlaat het. In die beloftes in Esegiël 34-39 word die terugkeer van die volk en die herstel van die verhouding met God voorwaardes vir 'n nuwe vrede. Hierdie twee temas kom ook telkens in die boek na vore, in besonder in die visioen van Esegiël 40-48, sonder dat daar 'n eksplisiete verwysing na vrede is.

\section{Erkenning Mededingende belange}

Die outeur verklaar hiermee dat hy geen finansiële of persoonlike verbintenis het met enige party wat hom nadelig of voordelig kon beïnvloed het in die skryf van hierdie artikel.

\section{Literatuurverwysings}

Ackroyd, P.R., 1968, Exile and restoration, SCM Press, London.

Allen, L.C., 1990, Ezekiel 20-48, Word, Dallas, TX. (Word Biblical Commentary 29).

Allen, L.C., 1994, Ezekiel 1-19, Word, Dallas, TX. (Word Biblical Commentary 28).

Batto, B.F., 1987, 'The covenant of peace: A neglected ancient near eastern motif', Catholic Biblical Quarterly 49, 187-211. 
Block, D.I., 1997, The Book of Ezekiel chapters 1-24, Eerdmans, Grand Rapids, MI. (New International Commentary on the Old Testament).

Block, D.I., 1999, The Book of Ezekiel chapters 25-48, Eerdmans, Grand Rapids, MI. (New International Commentary on the Old Testament).

Brueggemann, W., 1988, 'Truth-telling and peacemaking. A reflection on Ezekiel', The Christian Century, November 30, 1096-1098.

Craigie, P.C., 1991, 'Jeremiah', in P.C. Craigie, P.H. Kelly \& J.F. Drinkard jr. (eds.), Jeremiah 1-25, Word, Dallas, TX. (Word Biblical Commentary 26). (According to the Foreword [page $x$ ] the commentary is the work of Craigie up to 8:4).

Crane, A.S., 2008, Israel's restoration. A textual-comparative exploration of Ezekiel 36-39, Brill, Leiden/Boston. (Vetus Testamentum Supplements 122).

Darr, K.P., 1987, 'The wall around paradise. Ezekelian ideas about the future', Zeitschrift für die alttestamentliche Wissenschaft 37, 271-279.

Egger-Wenzel, R., 2010, 'Covenant of peace (ברית שלום) - an eschatological term?', in J. Liesen \& P.C. Beentjes, Visions of peace and talk of war, pp. 35-68, De Gruyter, Berlin/New York, NY. (Deuterocanonical and cognate literature yearbook 2010).

Eichrodt, W., 1968, Der Prophet Ezekiel, 3. Aufl., Vandenhoeck \& Ruprecht, Göttingen. (Das Alte Testament Deutsch 22)

Gerleman, G., 1997, 'שלם šlm to have enough', Theological Lexicon of the Old Testament 3, 1337-1348.

Hanson, P.D. 1984, 'War and peace in the Hebrew Bible', Interpretation 38, 341-362. http://dx.doi.org/10.1177/002096438403800402

McKane. W., 1986, A critical and exegetical commentary on Jeremiah 1, Clark Edinburgh. (International Critical Commentary).
Oswalt, J.N., 1997, The Book of Isaiah, chapters 40-66, Eerdmans, Grand Rapids, MI. (New International Commentary on the Old Testament).

Penna, R., 2010, 'The God of peace, in the New Testament', in J. Liesen \& P.C. Beentjes (eds.), Visions of peace and talk of war, pp. 279-302, De Gruyter, Berlin/New York, NY. (Deuterocanonical and cognate literature yearbook 2010).

Roberts, J.J.M., 2004, 'The end of war in the Zion tradition: The imperialistic background of an Old Testament vision of worldwide peace', Horizons in Biblical Theology 26, 2-22. http://dx.doi.org/10.1163/187122004X00023

Sedlmeier, F., 2002, Das Buch Ezechiel Kapitel 1-24, Katholisches Bibelwerk, Stuttgart. (Neuer Stuttgarter Kommentar Altes Testament 21/1)

Sedlmeier, F., 2013, Das Buch Ezechiel Kapitel 25-48, Katholisches Bibelwerk, Stuttgart. (Neuer Stuttgarter Kommentar Altes Testament 21/2).

Smith, R.L., 1984, Micah-Malachi Waco, Word, TX. (Word Biblical Commentary 32).

Stendebach, F.J., 2006, 'שָ šālōm', Theological Dictionary of the Old Testament XV, 13-49.

Sweeney, M.S., 2013, Reading Ezekiel. A literary and theological commentary, Smyth \& Helwys, Macon, GA.

Van Rooy, H.F., 2012, 'Esegiël 33 as wentelpunt in die boek van Esegiël', In die Skriflig/ In Luce Verbi 46(1), 6 pages. http://dx.doi.org/10.4102/ids.v46i1.51

Zimmerli, W., 1979, Ezekiel 1, Fortress, Philadelphia, PA. (Hermeneia).

Zimmerli, W., 1983, Ezekiel 2, Fortress, Philadelphia, PA. (Hermeneia). 